\title{
IMPLEMENTASI TQM DALAM PENGELOLAAN ZAKAT DI KOTA MALANG
}

\author{
Sudirman dan Sri Eko Ayu Indrawati \\ Fakultas Syariah UIN Maulana Malik Ibrahim Malang \\ e-Mail : sudirmanhasan@yahoo.co.id
}

\begin{abstract}
Abstrak
Muslim community awareness on performing zakat (alms) rises in line with social economic life development of the community. A number of alms organizations compete to design activities to attract people and to propose more professional and transparent management. Particularly in Malang, there are several alms institution branches which have national reputation such as Yayasan Dana Sosial al-Falah (YDSF) and Baitul Mal Hidayatullah $(B M H)$. In relation with alms management, this research raises the on integrated quality management in alms management. Integrated quality management in this research refers to Total Quality Management. This research focuses on the application of TQM principles at YDSF and BMH. Both institutions are compared in terms of several aspects covering their innovation in satisfying customers, those who give the alms, people who are illegible to get alms, and people within the management (amil). The result, the model of alms management in both institutions are the appropriate management for alms management especially in Malang.

Kesadaran umat Islam akan kewajiban menunaikan zakat semakin meningkat seiring dengan taraf kehidupan sosial ekonomi umat yang berkembang pesat. Sejumlah lembaga zakat berlomba merancang kegiatan untuk menarik muzakki dan menawarkan pengelolaan yang lebih profesional dan transparan. Khusus di kota Malang, telah berdiri cabangcabang lembaga zakat yang memiliki reputasi nasional, seperti Yayasan Dana Sosial alFalah (YDSF) dan Baitul Mal Hidayatullah (BMH). Berkaitan dengan manajemen zakat, penelitian ini mengangkat isu tentang manajemen mutu terpadu dalam pengelolaan zakat. Manajemen mutu terpadu dalam penelitian ini disebut Total Quality Management. Penelitian ini melihat aplikasi prinsip-prinsip TQM di YDSF dan BMH. Kedua lembaga tersebut diperbandingkan dalam beberapa unsur antara lain inovasi mereka dalam rangka memuaskan pelanggan yang dalam hal ini muzakki, mustahiq, dan amil. Model pengelolaan zakat di kedua lembaga tersebut merupakan gambaran tentang manajemen yang tepat untuk pengelolaan zakat, khususnya di Kota Malang.
\end{abstract}

Kata Kunci : Zakat, Lembaga Zakat, TQM (Total Quality Management)

Zakat merupakan ajaran yang melandasi tumbuh kembangnya sebuah kekuatan sosial ekonomi umat Islam. Seperti empat rukun Islam yang lain, ajaran zakat menyimpan beberapa dimensi yang kompleks meliputi nilai privat-publik, vertikal-horizontal, serta ukhrawi-duniawi. Nilai-nilai tersebut merupakan landasan pengembangan kehidupan kemasyarakatan yang komprehensif. Bila semua dimensi yang terkandung dalam ajaran zakat ini dapat diaktualisasikan, maka zakat 
sebagaimana pendapat Sofwan Idris $^{1}$ akan menjadi sumber kekuatan yang sangat besar bagi pembangunan umat menuju kebangkitan kembali peradaban Islam.

Untuk mengilustrasikan betapa pentingnya kedudukan zakat, al-Qur'an dengan sangat jelas menyebut kata zakat (al-zakat) yang dirangkaikan dengan kata shalat (alshalat) sebanyak 72 kali, menurut hitungan Ali Yafie ${ }^{2}$ atau sekitar 30 menurut Yusuf Qardhawi $^{3}$. Hal ini dapat diinterpretasikan bahwa penunaian zakat memiliki urgensi yang sebanding dengan pendirian shalat, seperti nampak dalam surat al-Baqarah ayat 43 yang mengungkapkan bahwa shalat dan zakat merupakan dua pilar utama dari keislaman seseorang menurut Qurais Shihab. ${ }^{4}$

Lebih lanjut, dalam membincang masalah zakat, pembahasan seputar manajemen merupakan suatu topik yang menarik. Pada umumnya, zakat dipahami sebagai ibadah yang tidak perlu menggunakanjasa perantara karena bisa langsung diberikan kepada pihak yang berhak. Bahkan, sebagian masyarakat menilai bahwa pemberian secara langsung dapat memberikan kepuasan tersendiri bagi para muzakki. Mereka merasa gembira karena zakatnya diterima langsung oleh mustahiq, berbeda halnya dengan zakat yang

${ }^{1}$ Safwan Idris, Gerakan Zakat dalam Pemberdayaan Ekonomi Umat, Pendekatan Transformatif (Jakarta: Citra Putra Bangsa 1997), h. 33

${ }^{2}$ Ali Yafie, Menggagas Fikih Sosial: Dari Soal Lingkungan Hidup, Asuransi Hingga Ukhuwah (Bandung: Mizan, 1995), h. 231.

${ }^{3}$ Yusuf Qardhawi, Figh al-Zakat (Jilid I, Beirut: Muassasah al-Risalah 1997), h. 42.

${ }^{4}$ M. Qurash Shihab, Tafsir Al-Mishbah (Tangerang: Lentera Hati 2000), h. 170-173. AlGhazali terkenal dengan buah pikirannya untuk membersihkan jiwa manusia secara personal. Satu hal yang kurang mendapat perhatian dari al-Ghazali adalah dimensi sosial yang mana zakat merupakan jalan yang paling relevan. Fokus yang digelutinya adalah bagaimana manusia menyetir kalbunya sehingga segala kewajiban yang dipikulnya dapat dilakukan dengan sadar hati. Konsep fastabiqu al-khairat yang sering didengungkan juga masih dipahami secara formalistis. Orang lebih suka membangun tempat ibadah ketimbang menyantuni fakir miskin. Pendekatan yang terlalu personal nampak terlalu dominan sehingga pendekatan kesalehan sosial kelihatannya tertinggal, lihat Masdar F Mas'udi, Keadilan, Risalah Zakat (Pajak) dalam Islam, (Jakarta: Pustaka Firdaus Masdar, 1993), h. 39. diberikan melalui lembaga pengelola zakat. Distribusi zakat melalui lembaga tidak dapat dipantau oleh muzakki dan bahkan mereka khawatir zakat mereka disalahgunakan untuk pos-pos yang tidak semestinya.

Tahap-tahap yang dilakukan dalam manajemen menurut James Stoner, seperti dikutip Eri Sudewo ${ }^{5}$, meliputi proses perencanaan, pengorganisasian, pengarahan dan pengawasan. Berbeda dengan manajemen tradisional yang dianggap sebagai penyebab lemahnya kepercayaan masyarakat, manajemen modern menjadikan profesi pengelola zakat sebagai salah satu pilihan pekerjaan denganlevel "white collar (pekerjaan terhormat)" bukan lagi "blue collar (pekerjaan rendahan)" sebagaimana sering dibayangkan orang. Tidak heran kemudian jika bermunculan eksekutif muda Muslim dengan keahlian di bidang manajemen zakat, seperti yang telah dirintis Institut Manajemen Zakat (IMZ) yang kini berubah nama menjadi Indonesia Magnificience of Zakat sebagai institusi pencetak ahli manajemen zakat. ${ }^{6}$

Dengan semakin butuhnya masyarakat terhadap lembaga zakat yang terpercaya, kini telah hadir di Indonesia sejumlah lembaga zakat yang merancang kegiatan untuk menjaring muzakki dan menawarkan pengelolaan yang lebih profesional, tepat sasaran, dan transparan. Khusus di kota Malang, telah berdiri cabang-cabang lembaga zakat yang memiliki reputasi nasional, seperti Yayasan Dana Sosial al-Falah (YDSF) dan Baitul Mal Hidayatullah (BMH). Sekilas tentang YDSF, lembaga ini didirikan pada tanggal 1 Maret 1987 dan saat ini telah menyebar di lebih dari 25 propinsi di Indonesia. Jumlah donaturnya telah mencapai ratusan ribu dengan berbagai potensi, kompetensi, fasilitas, dan otoritas dari kalangan birokrasi, profesional, swasta, dan masyarakat umum. YDSF telah dikukuhkan menjadi Lembaga Amil Zakat Nasional oleh Menteri Agama Republik Indonesia dengan SK

\footnotetext{
${ }^{5}$ Eri Sudewo, Manajemen Zakat, (Jakarta: Institut Manajemen Zakat, 2004), h. 63

${ }^{6}$ Sudirman, Zakat dalam Pusaran Arus Modernitas, (Malang: UIN Malang Press, 2007), h. 150.
} 
No.523 tanggal 10 Desember 2001. Melalui direktorat pendayagunaan dana Konsorsium Pendidikan Islam (KPI), Pusat Dakwah (PUSDA), dan Pusat Layanan Sosial Masyarakat (PLASMA), YDSF semakin meneguhkan pendayagunaan dana secara efektif dan produktif. Paradigma prestasi YDSF sebagai lembaga pendayagunaan dana yang amanah dan profesional menjadikannya sebagai salah satu lembaga pengelola zakat, infaq, dan sedekah (ZIS) yang maju di Indonesia.

Di sisi lain, BMH merupakan organisasi non profityangberakardariPondokPesantren Hidayatullah di Balikpapan, Kalimantan Timur yang didirikan pada tanggal 7 Januari 1973 oleh Abdullah Said. Kemudian, lembaga ini berkembang dan membentuk berbagai amal usaha di bidang sosial, pendidikan, dakwah, dan ekonomi. Di antaranya adalah membentuk lembaga amal usaha dalam bidang penghimpunan, pengelolaan dan pendayagunaan (penyaluran) dana ZISWAF (Zakat, Infaq, Sedekah, Wakaf) yang diberi nama Baitul Maal Hidayatullah yang biasa disingkat $\mathrm{BMH}$. Tepat tanggal 15 Februari 2001, BMH resmi dikukuhkan sebagai Lembaga Amil Zakat Nasional (LAZNAS) dengan SK Menteri Agama No. 538 Tahun 2001. Saat ini, BMH berkantor pusat di daerah Pejaten Barat, Pasar Minggu, Jakarta Selatan. Orientasi kegiatannya adaah memberdayakan masyarakat miskin melalui pengelolaan dana sosial masyarakat, antara lain melalui pintu zakat, infaq, sedekah, wakaf.

Berkaitan dengan manajemen zakat, penelitian ini mengangkat isu tentang manajemen mutu terpadu dalam pengelolaan zakat. Manajemen mutu terpadu dalam penelitian ini disebut Total Quality Management (dalam tulisan ini akan sering disingkat TQM). TQM merupakan salah satu terobosan manajemen yang umumnya dilakukan oleh perusahaan besar, seperti Xerox, IBM Rochester, dan Motorola, dalam rangka meningkatkan kualitas produk yang pada muaranya dapat memuaskan konsumen ${ }^{7}$. Semakin banyak konsumen yang puas dengan barang yang mereka beli, semakin sering mereka menggunakan produk tersebut. Konsekuensinya, perusahaan itu akan meraih keuntungan yang besar. ${ }^{8}$ TQM pada fase berikutnya banyak dilirik oleh perusahaan penyedia jasa, misalnya FedEx (jasa pengiriman). Fokus kepada pelanggan yang menjadi ciri khas TQM menjadikan perusahaan-perusahaan yang bergerak di bidang layanan kepada masyarakat itu memperoleh manfaat yang tidak kalah besarnya dengan perusahaan produsen barang. Oleh karenanya, TQM semakin menjadi sesuatu yang tak terelakkan dalam kompetisi global yang kian ketat.

TQM mulai diterapkan di lembaga-lembaga filantropi yang bergerak di bidang pelayanan pengelolaan zakat dan wakaf. Sebagai contoh, Islamic Relief Amerika yang berdiri pada tahun 1993 telah mendapatkan bintang 4 (four stars) dari Charity Navigator dalam manajemen filantropinya. ${ }^{9}$ Lembaga yang bermarkas di Alexandria, Virginia ini bergerak di bidang pengelolaan zakat, infaq, dan sedekah. Pada tahun 2011 ini, lembaga tersebut berencana melakukan pengumpulan

\footnotetext{
${ }^{7}$ Stephen George and Arnorld Weimerskirch, Total Quality Management, Strategies and techniques Proven at Today's Most Successful Companies (New York: John Wiley and Sons, Inc 1994), h. vi-vii

${ }^{8}$ Berbagai contoh perusahaan yang sukses telah menjalankan prinsip TQM disajikan secara komprehensif oleh George dan Weimerskirch (1998) dalam bukunya Total Quality Management: Strategies and Techniques Proven at Today's Most Successful Companies. Tidak kurang dari 51 perusahaan besar dunia yang telah berhasil mendulang untung berlipat karena mereka berhasil menerapkan prinsip-prinsip TQM dalam bisnisnya.

${ }^{9}$ Dalam situsnya www.islamicreliefusa. org (diakses tanggal 3 Mei 2011), dijelaskan bahwa lembaga ini telah diuji kinerjanya oleh lembaga terbesar pengamat karitas, Charity Navigator, dan telah memperoleh pengakuan sebagai lembaga yang mendapatkan penghargaan bintang empat (sempurna) selama delapan tahun berturut-turut. Untuk tahun 2011 ini, Islamic Relief USA menggunakan 93,8\% dari dana yang diterima untuk berbagai program dan hanya menggunakan 3,2\% dananya untuk kebutuhan administrasi. Informasi ini dapat dilihat langsung di situs Charity Navigator di www.charitynavigator.org (diakses tanggal 3 Mei 2011).
} 
dana dari pintu wakaf. $^{10}$ Profesionalisme yang ditunjukkan mereka mengukuhkan bahwa TQM telah diterapkan di lembaga tersebut. Pelayanan yang prima kepada donatur (donors) dan penerima manfaat dana (beneficieries) sudah menjadi bagian integral dalam manajemen mereka. ${ }^{11}$

Melihat betapa pentingnya penggunaan TQM dalam manajemen, khususnya dalam pengelolaan zakat, penelitian ini melihat aplikasi prinsip-prinsip TQM di YDSF dan BMH. Kedua lembaga tersebut diperbandingkan dalam beberapa unsur antara lain inovasi mereka dalam rangka memuaskan pelanggan yang dalam hal ini muzakki, mustahiq, dan amil. Dengan mempelajari model pengelolaan zakat di kedua lembaga tersebut akan diperoleh gambaran tentang manajemen yang tepat untuk pengelolaan zakat, khususnya di kota Malang. Dengan demikian, penelitian ini dirasa penting untuk pengembangan zakat di kota Malang khususnya, dan Indonesia pada umumnya.

\section{Teori Total Quality Management}

\section{Mutu (Quality)}

Sejumlah pakar mendefinisikan mutu secara berbeda. Tjiptono dan Diana mendefinisikan mutu sebagai suatu kondisi dinamis yang berhubungan dengan produk, jasa, manusia, proses, dan lingkungan yang memenuhi atau melebihi harapan ${ }^{12}$. Gaspersz menyebutkan bahwa mutu mengacu pada

${ }^{10}$ Induk organisasi ini di tingkat internasional bertempat di Birmingham, Inggris. Namanya adalah Islamic Relief Worldwide (IRW). IRW yang berdiri sejak tahun 1984 telah mengelola zakat, infaq-sedekah, dan wakaf (islamicrelief.org diakses tanggal 2 Mei 2011).

${ }^{11}$ Penulis pernah berkunjung ke markas Islamic Relief USA pada tanggal 11-24 Oktober 2010 atas dukungan dari Fulbright Scholarship. Di lembaga ini, penulis melakukan observasi dan wawancara dengan CEO, Abed Ayyub, dan sejumlah pejabat pentingnya seputar penerapan Total Quality Management dalam pengelolaan zakat, infaq, dan sedekah. Dari kunjungan tersebut, penulis terkesan dengan cara mereka menggunakan teknologi dalam penggalangan dana serta profesionalisme dalam melayani donatur dan mitra kerja.

${ }^{12}$ Fandi Tjiptono dan Anastasia Diana, Total Quality Management (Yogyakarta: Andi, 2007), h.4. dua pengertian pokok, yaitu mutu terdiri dari sejumlah keistimewaan produk dan mutu terdiri dari segala sesuatu yang bebas dari kekurangan. ${ }^{13}$

\section{Total Quality Management (TQM)}

Seperti halnya pengertian kualitas, definisi Total Quality Management juga bermacammacam. TQM diartikan Ishawaka sebagai perpaduan semua fungsi dari perusahaan ke dalam falsafah holistik yang dibangun berdasarkan konsep kualitas, kerja tim, produktifitas, dan pengertian serta kepuasan pelanggan. Definisi lain seperti yang diutarakan oleh Tjiptono dan Diana adalah suatu pendekatan dalam menjalankan usaha yang mencoba untuk memaksimalkan daya saing organisasi melalui perbaikan terusmenerus atas produk, jasa, manusia, proses, dan lingkungannya. ${ }^{14}$ TQM hanya dapat dicapai jika karakter TQM sebagai berikut diperhatikan secara serius. ${ }^{15}$ (1) Fokus pada pelanggan, baik pelanggan internal maupun eksternal. ${ }^{16}$ Pelanggan internal dalam penelitian ini adalah para karyawan

\section{${ }^{13}$ Vincent Gaspersz, Total Quality Management (Jakarta: Gramedia Pustaka Utama, 2001), h.5. \\ ${ }^{14}$ Fandi Tjiptono dan Anastasia Diana, Total, h.120. \\ ${ }^{15}$ M.N. Nasution, Manajemen Mutu Terpadu} (Jakarta: Ghalia Indonesia, 2001), h. 28-29.

${ }^{16}$ Untuk memenuhi harapan pelanggan, cara yang dapat dilakukan adalah mendengar respon dari pelanggan, khususnya apa yang bisa membuat mereka puas. Dalam hal ini, ternyata pelanggan tidak hanya dibatasi pada pelanggan di luar perusahaan, tetapi ada pula pelanggan dalam perusahaan, yakni orang yang menerima pekerjaan dari karyawan sebelumnya. Ia akan memberikan kontribusinya ke produk tersebut sebelum menyerahkannya ke karyawan berikutnya. Di perusahaan, pelanggan internal dapat diketahui dari jalur ke bawah (downline) yang akan memberikan sentuhan selanjutnya. Di restoran, pelanggan internal kokiadalah para pramusaji sebelum akhirnya pramusaji memberikan ke pelanggan luar. Bila restoran itu ingin memuaskan pelanggan, koki harus memuaskan pramusaji yang akhirnya juga memberikan kepuasan kepada pelanggan/konsumennya. Jika kepuasan pelanggan internal disepakati, rantai kualitas akan dapat dibuat untuk mencapai kepuasan pelanggan eksternal. Untuk membangun budaya kualitas, perlu dibiasakan untuk mengidentifikasi kebutuhan pelanggan internal yang pada akhirnya dapat memberikan pelayanan maksimal untuk pelanggan eksternal. Ini merupakan proses yang harus terjadi . Lihat John Bank, the Essence of Total Quality Management, (Essex: Pearson Education Limited 2000), h. 26. 
pengelola wakaf sedangkan pelanggan eksternalnya adalah wakif dan mitra kerja Memiliki obsesi yang tinggi terhadap kualitas. (2) Menggunakan pendekatan ilmiah dalam pengambilan keputusan dan pemecahan masalah. (3) Memiliki komitmen jangka panjang. (4) Membutuhkan kerjasama tim. (5) Memperbaiki proses secara berkesinambungan. (6) Menyelenggarakan pendidikan dan pelatihan Memberikan kebebasan yang terkendali. (7) Memiliki kesatuan tujuan. Adanya keterlibatan dan pemberdayaan karyawan.

Untuk melengkapi karakter di atas, perlu juga diungkap 14 poin prinsip manajemen Deming. Butir-butir tersebut adalah ${ }^{17}$ : (1) penciptaan tujuan yang mantap ke arah perbaikan barang atau jasa dengan tujuan menjadi lebih kompetitif, (2) pengadopsian cara berfikir baru, misalnya transformasi manajemen, (3) penghentian ketergantungan pada inspeksi masal untuk memperoleh kualitas, (4) penghentian praktik bisnis dengan hanya bergantung pada harga. Hal ini bisa dilakukan dengan membina hubungan jangka panjang dengan pemasok yang berdasarkan kesetiaan dan kepercayaan, (5) peningkatan perbaikan terus-menerus pada sistem produksi dan pelayanan sehingga dapat meningkatkan kualitas dan menurunkan biaya, (6) pelembagaan pelatihan kerja, (7) pembagian kepemimpinan, penghapusan ketakutan sehingga setiap orang dapat bekerja secara efektif, (8) penghapusan hambatan-hambatan di antara departemen, (9) penghapusan slogan, desakan, dan target kepada karyawan, (10) penghapusan kuota produksi kerja dan manajemen serba sasaran., (11) penghapusan penghalang yang merampas para pekerja dari hak kebanggaan kerja. Juga, penghapusan penghalang yang merampok orang-orang yang berada dalam manajemen dan rekayasa dari hak kebanggaan kerja, (12) pelembagaan program pendidikan dan pengembangan diri secara serius, (13) penggerakan setiap orang untuk

${ }^{17} \mathrm{~W}$. Edwards Deming, Out of the Crisis, (Cambridge: MIT Press 2002),h.23-24. mencapai transformasi di atas.

\section{Prinsip TQM}

TQM merupakan sebuah konsep yang berupaya melaksanakan sistem manajemen kelas dunia. Untuk itu, perlu perubahan besar dalam budaya dan sistem nilai suatu organisasi. Hensler dan Brunell, sebagaimana dikutip Nasution menyatakan bahwa ada empat prinsip utama dalam TQM: ${ }^{18}$ Pertama, kepuasan Pelanggan, dalam TQM, konsep mengenai kualitas dan pelanggan diperluas. Kualitas tidak lagi hanya bermakna kesesuaian dengan spesifikasi tertentu, tetapi kualitas tersebut ditentukan oleh pelanggan. Pelanggan sendiri meliputi pelanggan internal dan pelanggan eksternal. Kebutuhan pelanggan diusahakan untuk dipuaskan dalam segala aspek, termasuk dalam harga, keamanan, dan ketepatan waktu. Dengan demikian, segala gerak dan aktifitas perusahaan harus ditujukan untuk memuaskan pelanggan. Kedua, penghormatan terhadap setiap orang, Dalam perusahaan yang berkualitas internasional, setiap karyawan dipandang sebagai individu yang memiliki bakat dan kreatifitas yang unik. Denganbegitu, karyawan merupakansumber daya organisasi yang paling bernilai. Oleh sebab itu, setiap individu dalam organisasi diperlakukan dengan baik dan diberi kesempatan untuk terlibat dan berpartisipasi dalam tim pengambil keputusan. Ketiga, manajemen berdasarkan fakta. Setiap keputusan selalu didasarkan pada data, bukan sekedar perasaan. Ada dua konsep terkait dengan masalah ini. (1) prioritisasi, yakni suatu konsep bahwa perbaikan tidak dapat dilakukan pada semua aspek pada saat yang sama, mengingat keterbatasan sumber daya yang ada. Oleh sebab itu, dengan menggunakan data, manajemen dan tim dalam organisasi dapat mengarahkan usahanya pada situasi tertentu yang penting. (2) variasi atau variabilitas kinerja manusia. Data statistik dapat memberikan gambaran

${ }^{18}$ Nasution, M.N..Manajemen Mutu Terpadu. (Jakarta: Ghalia Indonesia, 2001), h. 33-34 
tentang variabilitas yang merupakan bagian yang wajar dari setiap sistem organisasi. Dengan demikian, manajemen dapat memprediksikan hasil dari setiap keputusan dan tindakan yang dilakukan. Keempat, Perbaikan berkesinambungan

Agardapatsukses, setiapperusahaan perlu melakukan proses secara sistematis dalam melaksanakan perbaikanberkesinambungan. Konsep yang berlaku di sini adalah siklus PDCA (plan-do-check-act) yang terdiri dari langkah-langkah perencanaan, pelaksanaan rencana, pemeriksaan hasil pelaksanaan rencana, dan tindakan korektif terhadap hasil yang diperoleh.

Sedikit berbeda dengan Hensler dan Brunell, Arthur Tenner mengemukakan tiga prinsip utama dalam TQM. Ketiga hal tersebut adalah: Pertama, Fokus kepada Pelanggan (focus on customer). Kualitas didasarkan kepada konsep bahwa setiap orang mempunyai pelanggan. Keinginan dan harapan pelanggan harus dipenuhi setiap saat oleh sebuah organisasi. Oleh sebab itu, untuk menentukan keinginan pelanggan, sejumlah analisis harus dilakukan agar tidak salah langkah. Kedua, Perbaikan proses (process improvement). Konsep peningkatan kualitas secara terus-menerus berawal dari asumsi bahwa sebuah hasil kerja merupakan akumulasi dari serangkaian langkah kerja yang saling terakit hingga muncullah output. Perhatian yang berkelanjutan terhadap setiap langkah dalam proses kerja merupakan satu hal yang harus dilakukan demi mengurangi outputyang berbeda-beda dan meningkatkan keterpercayaan proses. Tujuan pertama dari perbaikan yang berkesinambungan adalah proses yang tepercaya dalam artian bahwa output yang dihasilkan setiap waktu akan sama dan sesuai dengan standar yang ditentukan. Apabila variasi output telah diperkecil namun hasilnya belum dapat diterima, tujuan kedua dari perbaikan proses adalah mendesain ulang proses produksi sehingga memperoleh hasil yang lebih baik dan sesuai dengan harapan pelanggan. Ketiga, Keikutsertaan Total (total involvement).
Pendekatan ini dimulai dengan adanya pemimpin yang aktif dari manajemen senior dan mencakup usaha untuk menggunakan keahlian karyawan dari organisasi tersebut untuk meraih keuntungan persaingan di pasar. Karyawan di setiap jenjang diberi bekal untuk meningkatkan hasil kerja dengan bekerja sama dalamstrukturbekerjayangfleksibel dalam penyelesaian masalah, peningkatan proses, dan memberikan kepuasan pada pelanggan. Begitu pula mitra kerja luar harus dilibatkan secara aktif dengan bekerja sama dengan karyawan yang terdidik untuk memberikan keuntungan bagi organisasi ${ }^{19}$.

Prinsip TQM yang ditawarkan Tenner dipilih menjadi alat analisis untuk melihat aplikasi TQM di YDSF dan BMH Malang.

\section{Sejarah YDSF}

Yayasan Dana Sosial al Falah (YDSF) didirikan pada tanggal 1 Maret 1987. Yayasan ini telah menjangkau masyarakat kurang mampu di 25 propinsi di Indonesia. Paradigma prestasi YDSF sebagai lembaga pendayagunaan dana yang amanah dan profesional, dengan menjadikannya sebagai lembaga pengelola zakat, infaq, dan sedekah (ZIS) terpercaya di Indonesia.

Bersama 88.449 donatur dengan berbagai potensi, kompetensi, fasilitas, dan otoritas dari kalangan birokrasi, profesional, swasta, dan masyarakat umum telah terajut bersama YDSF membentuk komunitas peduli dhuafa. Mereka, dengan segala kemampuan terbaiknya, telah memberikan kontribusi, cinta, dan kepedulian dalam membangun negeri ini.

YDSF yang dikukuhkan menjadi Lembaga Amil Zakat Nasional oleh Menteri Agama Republik Indonesia dengan SK No.523 tanggal 10 Desember 2001 menjadi entitas yang menaruh perhatian mendalam pada kemanusiaan yang universal. Melalui Divisi Penyaluran YDSF semakin meneguhkan pendayagunaan dana secara syar'i, efisien, efektif

${ }^{19}$ Arthur R Irving J. DeToro Tenner, Total Quality Management, Three Steps to Continuous Improvement, (Massachusetts: Addison-Wesley Publishing Company, Inc1992), h. 32-33 
\& produktif. Sebagai lembaga pengelola dana ZIS yang makin terasa manfaatnya, YDSF akan menjadi mitra terpercaya dalam penyaluran dana anda yang akan disalurkan kepada umat atau kaum yang berhak. ${ }^{20}$

Lembaga YDSF memiliki visi dan misi, sebagai tujuan utama yang mengutamakan kepuasan donatur atau mustahiq. ${ }^{21}$ Visi YDSF adalah menjadi Organisasi Pengelola Zakat, Infaq, Shadaqah dan Wakaf Nasional terpercaya yang selalu mengutamakan kepuasan donatur dan mustahik. Adapun misinya adalah a) memberikan pelayanan prima kepada donatur melalui program-program layanan donaturyang didukung oleh jaringan kerja yang luas, sistem manajemen yang rapi serta SDM yang amanah dan professional, $b$ ) melakukan kegiatan pendayagunaan dana yang terbaik dengan mengutamakan kegiatan pada sektor pendidikan, dakwah, yatim, masjid, dan kemanusiaan untuk menunjang peningkatan kualitas dan kemandirian umat, dan c) memberikan keuntungan dan manfaat yang berlipat bagi donatur dan mustahik.

\section{Sejarah BMH}

Baitul Maal Hidayatullah merupakan organisasi non profit yang tidak terlepas dari akar sejarah pendirian pondok pesantren Hidayatullah di Balikpapan, Kalimantan Timur. Dengan memiliki tujuan yang bermanfaat untuk masyarakat sekitarnya atau umat yaitu memberdayakan masyarakat miskin melalui pengelolaan dana sosial dari masyarakat yang mempunyai rezeki lebih (zakat, infaq, sedekah, wakaf) serta dana lain yang halal dan sesuai hukum dari perseorangan, lembaga dan perusahaan. ${ }^{22}$

Pada 7 Januari 1973 Pesantren Hidayatullah didirikan dalam bentuk Yayasan/ Organisai Sosial (Orsos) oleh Ust. Abdullah Said (Alm) di Balikpapan-Kalimantan Timur. Kemudian, lembaga ini berkembang dan

\footnotetext{
${ }^{20} \mathrm{http}: / /$ www.ydsf.org/profil-organisasi/sekilasydsf, diakses pada tanggal 5 Juli 2011.

${ }^{21} \mathrm{http}: / /$ www.ydsf.org/profil-organisasi/visi-danmisi, diakses pada tanggal 5 Juli 2011.

${ }^{22}$ Profil,http://www.bmh.or.id/profile/sejarah.html, diakses pada tanggal 5 Juli 2011.
}

membentuk berbagai amal usaha di bidang sosial, pendidikan, dakwah, dan ekonomi. Di antaranya adalah membentuk lembaga amal usaha dalam bidang penghimpunan, pengelolaan dan pendayagunaan (penyaluran) dana ZISWAF (Zakat, Infaq, Sedekah, Wakaf) yang diberi nama Baitul Maal Hidayatullah dan biasanya disingkat $\mathrm{BMH}$.

Melalui Musyawarah Nasional I di Balikpapan pada tanggal 9-13 Juli 2000, Hidayatullah berkembang lagi menjadi Organisasi Kemasyarakatan (Ormas) dan memposisikan diri sebagai "Jama'atul Min Jama'atil Muslimin". Pada tahun 2008, Hidayatullah sudah beranggotakan sekitar 12 juta orang dan telah menjadi Ormas terbesar ke-3 (setelah NU dan Muhammadiyah) dengan jaringan kerja di 5.400 Kecamatan dan 489 Kabupaten/Kota di 33 propinsi seluruh Indonesia. ${ }^{23}$ Pada 15 Februari 2001, BMH resmidikukuhkansebagai(LAZNAS) dengan SK Menteri Agama No. 538 Tahun 2001. Untuk penelitian ini, penulis memilih salah satu kantor cabang $\mathrm{BMH}$ yang bertempat di Dau, Malang.

Secara legal BMH telah memiliki akta yang tercatat di notaris Lilyk, SH, SP.1, dengan akta No.17 tanggal 18 Nopember 2005. Selain itu, dari sistem pengelolaan yang baik dan perkembangannya BMH telah mendapatkan SK. Menteri Agama RI No.538 Tahun 2001 tentang Pengukuhan Sebagai LAZNAS (Lembaga Amil Zakat Nasional) dan SK. Menteri Hukum dan HAM RI No.CHT.01.09-302 TH.2005. ${ }^{24}$

\section{Penerapan Nilai Total Quality Management di Yayasan Dana Sosial Al-Falah dan Baitul Mal Hidayatullah}

Bagian ini menguraikan tentang pelaksanaan tiga nilai Total Quality Management di Yayasan Dana Sosial al-Falah Malang dan Baitul Maal Hidayatullah Malang. Tiga prinsip tersebut adalah pelayanan kepada pelanggan, perbaikan berkesinambungan,

\footnotetext{
${ }^{23}$ Republika, 5 November 2008.

${ }^{24} \mathrm{http}$ ://www.bmh.or.id/profile/legal-formal.html, diakses pada tanggal 5 Juli 2011.
} 
dan keterlibatan seluruh komponen lembaga dalam meraih tujuan. Ketiganya merupakan penjabaran dari teori Tenner tentang TQM sebagaimana telah diulas pada bab II. Dipilihnya teori Tenner tersebut karena tiga prinsip itu dapat dianggap mewakili indikator keberhasilan penerapan TQM di sebuah lembaga.

\section{Pelayanan terhadap Pelanggan YDSF}

Pelayanan yang proporsional terhadap pelanggan eksternal (muzakki dan mustahiq) maupun pelanggan internal (amil) merupakan salah satu tujuan utama dari YDSF. Pelayanan ini merupakan hasil kreatifitas YDSF Malang untuk memberikan kepuasan terhadap pelanggan. Untuk melayani pelanggan eksternal, YDSF menyediakan fasilitas komunikasi via SMS center, website, dan facebook. Adapun untuk keluhan atau pertanyaan dari para mustahiq atau muzakki telah disediakan forum komunitas. Tujuannya adalah agar para muzakki ataupun mustahiq dapat secara langsung dan terbuka atas keluhan dan pertanyaannya. YDSF telah menyediakan petugas khusus di bidang pelayanan pelanggan di meja customer service. Pola seperti ini berdasarkan tujuan utamanya, yaitu fokus kepada pelanggan sehingga pelanggan akan merasa dilayani secara baik dan cepat. ${ }^{25}$

Sejumlah program telah disediakan untuk pelanggan. Beberapa program yang dijalankan oleh YDSF di berbagai bidang yang terdiri dari dakwah, masjid, dan santunan. Untuk dakwah, YDSF menyediakan sejumlah program seperti pembinaan dai-dai desa, layanan konsultasi syariah, layanan ceramah dan khatib, dan berbagai program-program kemitraan untuk penyebaran nilai-nilai keislaman. Adapun untuk masjid, YDSF melayani pendidikan dan pemberdayaan imam masjid, rehab masjid dan operasional, serta pelatihan manajemen masjid. Khusus untuk santunan, YDSF mempunyai sejumlah pos, yakni pos pendidikan, pos yatim, dan kemanusiaan. Ketiga hal ini menjadi ujung

\footnotetext{
${ }^{25}$ Ririn, wawancara, 08 Juli 2011.
}

tombak penyaluran amanah zakat muzakki agar sampai kepada mustahiq secara tepat sasaran. Ini merupakan bentuk usaha YDSF untuk mewujudkan slogan mereka yang amanah dan profesional.

Untuk pelayanan pelanggan internal (amil), YDSF memberikan perhatian penuh terhadap kesejahteraan mereka sesuai proporsi amanat yang diembannya. Bagian amil ditentukan sebanyak $12,5 \%$. Selain pelayanan yang baik dan proporsional, pelanggan internal juga diberikan jaminan kesehatan. Salah satu alasannya adalah adanya resiko yang besar khususnya untuk karyawan lapangan dengan kondisi medan yang berbahaya saat membawa amanat besar dari YDSF untuk penyaluran. YDSF berusaha meningkatkan kesejahteraan karyawan secara bertahap sesuai porsi tugas yang diemban dengan jaminan kesehatan yang diberikan. Hal ini untuk melindungi karyawan dalam melaksanakan kewajibannya dan untuk mendapatkan haknya. Sebagai contoh, Ririn, Humas YDSF, mengatakan,

"Pernah saat salah satu karyawan membawa sejumlah uang yang akan disalurkan di daerah Sawojajar, ternyata terjadi hujan deras dan petir sehingga karyawan jatuh terpeleset akibat licinnya jalan dan ban bocor, maka pihak YDSF menjemput karyawan di tempat kejadian untuk diantar pulang dan mendapatkan sejumlah jaminan kesehatan dari resiko besar yang diemban dalam melakukan tugasnya ". ${ }^{26}$

Dari cerita tersebut dapat disimpulkan bahwaperhatianYDSFkepadakaryawancukup besar, lebih-lebih karyawan yang bertugas di lokasi yang rawan. Ini menunjukkan bahwa YDSF memberikan perhatian imbang baik pelanggan eksternal mapun internal.

\section{Pelayanan terhadap Pelanggan BMH}

Pelayanan yang baik dan seimbang dengan tujuan memberi kepuasan terhadap setiap pelanggan baik pelanggan eksternal (muzakki dan mustahiq) maupun pelanggan internal (amil/pekerja) merupakan tujuan utama dari BMH. Hal ini berdasarkan SOP (Standar Operasional Program) yang diten${ }^{26}$ Ririn, wawancara, 8 Juli 2011 
tukan oleh BMH Pusat. Pelayanan terhadap pelanggan eksternal maupun internal merupakan bagian terpenting dalam pengembangan $\mathrm{BMH}$ dan kepentingan umat. ${ }^{27}$

Untuk memberikan pelayanan terhadap pelangganeksternal(muzakki danmustahiq), $\mathrm{BMH}$ telah menyediakan media cetak dan elektronik untuk menerima keluhan dan pertanyaan dari pelanggan. Bagi mereka yang ingin mengakses informasi tentang penyaluran dananya ataupun kegiatan dari $\mathrm{BMH}$, mereka dapat mengaksesnya melalui media tersebut. Tentang hal itu, Bathy, Humas $\mathrm{BMH}$, mengatakan:

"meskipun BMH tidak menyediakan kotak saran dan layanan telepon bebas pulsa dengan alasan karena layanan telepon bebas pulsa masih membutuhkan anggaran dana yang cukup besar. Namun BMH tetap dapat melayani keluhan dan pertanyaan dari para muzakki dan mustahiq melalui telepon langsung ke kantor BMH Cabang Malang yang biasanya tampa menyebutkan nama".28

Solusi yang diberikan oleh BMH adalah dengan menyediakan media cetak yang berbentuk BMH News dan elektronik seperti website serta layanan telepon langsung. Hal ini dimaksudkan untuk menginformasikan bentuk kegiatan yang dilakukan oleh $\mathrm{BMH}$ dan laporan keuangan serta menjawab atau menanggapi pertanyaan atas keluh kesah pelanggan eksternal. Cara yang dilakukan oleh BMH untuk menanggapi komplain atas keluhan atau pertanyaan para muzakki dan mustahiq adalah dengan menjelaskan dan mendeskripsikan alasan BMH secara santun. Jika dimungkinkan, pertanyaan tersebut akan dimuat di media cetak BMH News beserta jawabannya.

Berbagai program telah dirancang oleh $\mathrm{BMH}$ untuk melayani pelanggan. Kegiatan tersebut terbagi dalam tiga kategori, yakni bidang pendidikan, dakwah, dan bidang sosial dan solidaritas kemanusiaan. Untuk pendidikan, BMH mendirikan Pusat Pendidikan Anak Sholeh (PPAS) yang memberikan santunan pendidikan, asrama, kon-

\footnotetext{
${ }^{27}$ Bathy, wawancara, 6 Juli 2011

${ }^{28}$ Bathy, wawancara, 06 Juli 2011
}

sumsi, untuk anak-anak yatim piatu dan anak dhuafa. Saat ini BMH telah memiliki 550 anak asuh. Selain itu, BMH juga mempunyai Pengembangan Sekolah Dhuafa (PSD) yang fungsinya untuk menyiapkan fasilitas pendidikan untuk kaum dhuafa dengan mengembangkan sekolah model alam. Kini lahan yang sudah siap digunakan seluas $6000 \mathrm{~m}^{2}$.

Lebih lanjut, di bidang dakwah, $\mathrm{BMH}$ mempuyai program DAMBAAN (Da'i Membangun Negeri) dan BIM (Bina Iman Muslim). Program dambaan melingkupi pengiriman da'ikedaerahrawan pemurtadan, rekruitmen da'i untuk disebarkan di Malang Raya, dan pembinaan da'i secara berkesinambungan. Hingga kini, da'i yang dimiliki oleh $\mathrm{BMH}$ sebanyak 15 orang dan sudah tersebar di Malang Raya. Untuk program BIM, BMH melayani konsultasi agama, melayani pengajian kantor, jama'ah pengajian, dan majelis ta'lim, dan melayani belajar dan mengajar al-Qur' an (MBA).

Terakhir, bidang yang cukup banyak menyedot perhatian muzakki adalah bidang sosial dan solidaritas kemanusiaan. BMH mempunyai program Sapa Gakin (Santunan Peduli Keluarga Miskin), KBN (Kurban Berkah Nusantara), IMS (Islamic Medical Service), dan Tanggap Bencana Nasional dan Ekonomi. Kesemuanya itu dimaksudkan untuk memudahkan bagi para muzakki untuk turut serta dalam menyelesaikan masalah yang dihadapi masyarakat luas. Dengan demikian, pelanggan $\mathrm{BMH}$, khususnya pelanggan eksternal, akan mudah menyalurkan donasinya dan dapat mengontrol kegiatan tersebut melalui sejumlah sarana yang telah disediakan BMH.

Adapun pelayanan terhadap pelanggan internal (amil atau pekerja) termasuk bagian dari prioritas utama $\mathrm{BMH}$. Amil adalah bagian tubuh dari $\mathrm{BMH}$ yang berperan penting untuk pengembangan $\mathrm{BMH}$. Merujuk pada al-Qur'an, bagian amil adalah $12,5 \%$. Oleh sebab itu, hal ini digunakan dasar meningkatkan kesejahteraan amil dan 
juga ketentuan dari SOP BMH Pusat.

Peningkatan kesejahteraan karyawan dilakukan secara bertahap. Upaya ini berkaitan langsung dengan banyak atau tidaknya dana yang terkumpul. Meskipun begitu, timpengembang BMHselaluberusaha semaksimal mungkin untuk memperhatikan kesejahteraan amil. Sebagai contoh, adanya jaminan kesehatan untuk para amil atau bantuan dana untuk amil yang sedang sakit yang diambilkan dari dana kemanusiaan BMH. Dalam hal ini, Bathy mengatakan:

"seperti pada jaminan kesehatan, pelanggan internal (amil atau pekerja) mendapatkan sejumlah uang untuk pengobatan sesuai dengan kondisi amil dan setara dengan kondisi keuangan BMH sendiri. Dan tidak hanya itu saja, seluruh karyawan menjenguk amil yang sakit sebagai bukti tanda kepedulian dengan sesama". ${ }^{29}$

Untuk tetap dapat melayani pelanggan internal maupun eksternal dengan semaksimal mungkin, $\mathrm{BMH}$ menyediakan petugas khusus di bidang pelayanan pelanggan, yaitu Divisi Humas. Divisi Humas di BMH ini sangat berpengaruh untuk pengembangan BMH baik secara internal ataupun eksternal. Prosedur program kerja Divisi Humas dalam melayani pelanggan disesuaikan dengan SOP yang telah ditentukan oleh BMH Pusat atau juga sesuai dengan permintaan dan kebutuhan pelanggan.

Memperhatikan usaha yang dilakukan oleh kedua lembaga di atas, nampak ada beberapapersamaanyang telahmerekalakukan. Pada prinsipnya, baik YDSF maupun BMH telah memberikan perhatian khusus kepada pelanggannya. Bagi mereka, pelanggan adalah nafas hidup. Tanpa pelanggan, baik internal maupun internal, kedua lembaga itu tidak akan pernah ada. Pelanggan bagi YDSF adalah garansi kehidupan mereka. Begitu juga BMH, pelanggan bagi lembagaini adalah bagian terpenting dalam pengembangan $\mathrm{BMH}$ dan kepentingan umat.

Untukmemberikan pelayanan terbaik bagi pelanggan eksternal, YDSF menyediakan se-

\footnotetext{
${ }^{29}$ Bathy, wawancara, 06 Juli 2011
}

jumlah fasilitas, seperti SMS center, website, dan facebook. Dengan fasilitas ini, para mustahiq atau muzakkidapatmendapatinformasi teraktual yang telah dilakukan YDSF. Bagi muzakki, majalah atau informasi online dapat menjadi bukti bahwa dana mereka tidak disalahgunakan. Muzakki yang ingin konsultasi juga bisa memanfaatkan fasilitas ini. Ini menunjukkan bahwa pelanggan eksternal telah mendapatkan pelayanan yang mereka harapkan sehingga dapat berefek pada meningkatnya kepercayaan mereka ke lembaga ini.

Tak jauh beda dengan itu, BMH juga melakukan beberapa terobosan untuk melayani pelanggan. Meskipun fasilitasnya tak selengkap YDSF, BMH berusaha memberikan pelayanan terbaik untuk pelanggan eksternalnya. BMH menyediakan media cetak yang berbentuk BMH News, media elektronik, dan layanan telepon. BMH News menjadi sarana komunikasi antara $\mathrm{BMH}$ dengan pelanggannya. Muzakki akan dapat mengetahui perkembangan mutakhir $\mathrm{BMH}$ sekaligus dapat mengecek rincian dana yang terkumpul. Mereka juga bisa menikmati konsultasi via telepon. Muzakki bisa menanyakan status zakatnya, misalnya apakah sudah diterima atau belum.

Khusus untuk pelanggan internal, YDSF dan BMH cukup memahami bahwa kegiatan pengelolan zakat bukanlah perkara ringan. Pekerjaan sebagai amil tidak bisa lagi menjadi pekerjaan sampingan. Oleh sebab itu, gaji karyawan secara proporsional adalah wajib adanya.Kedualembaga tersebut menentukan batas maksimal bagian amil adalah 12,5\%. Bagian ini sesungguhnya tidak nyata tertera di dalam al-Qur'an, khususnya dalam surat at-Taubah: 60. Ayat ini menyebut delapan golongan yang berhak mendapat bagian zakat. Satu di antaranya adalah amil. Oleh sebab itu, logika ditentukannya angka 12,5\% adalah satu per delapan bagian penerima zakat.

Kemudian, penentuan kesejahteraan karyawan di YDSF dan BMH didasarkan 
asas proporsional. Hal ini mudah dimengerti karena besar kecilnya gaji tergantung pada berat ringannya pekerjaan dan banyak sedikitnya dana yang terkumpul. Apabila semua karyawan memaklumi kebijakan ini, mereka akan terus semangat bekerja saling bahu-membahu tanpa adanya rasa iri antar sesama karyawan. Karyawan yang mempunyai tanggung jawab besar akan melaksanakan pekerjaannya dengan penuh tanggung jawab. Begitu pula karyawan yang bekerja di lapangan akan tetap fokus mengerjakan tugas yang menjadi bagiannya.

Untuk melihat persamaan dan perbedaan pelaksanaan pelayanan kepada pelanggan, berikut ini dipaparkan sebuah tabel yang merangkum hal tersebut.

Dari uraian di atas, dapat disimpulkan bahwa baik YDSF maupun BMH telah melaksanakan pelayanan kepada pelanggan dengan ciri masing-masing. Mereka berusaha memberikan fasilitas yang mudah untuk pelanggan eksternal dan kesejahteraan bagi pelanggan internal. Meskipun begitu, ada

\section{Perbaikan Proses YDSF yang Berkelanjutan}

\section{Peningkatan Kualitas}

Upaya dalam meningkatkan kualitas YDSF maka membutuhkan sarana dan prasarana untuk mencapai tujuan. Meskipun sarana dan prasarana yang dimiliki oleh YDSF tidak begitu lengkap, namun di setiap departemen sudah disediakan laptop dan alat komunikasi sebagai sarana untuk menyelesaikan tugas-tugas managemen. Selain itu, YDSF juga memiliki mobil ambulan sebagai inventaris saat kondisi tertentu dibutuhkan, misalnya untuk kegiatan kemanusiaan. Status dari mobil ambulan adalah wakaf dari salah satu donatur..$^{30}$

Bagi YDSF, karyawan adalah SDM yang menjalankan roda perkembangan dan peningkatan kualitas YDSF. Oleh sebab itu, perhatian khusus tentang pendidikan karyawan akan dapat meningkatkan kualitas YDSF secara umum. Untuk itu, YDSF tak segansegan untuk mengirim karyawan untuk belajar ke lembaga-lembaga sejenis guna menambah pengetahuan demi teraihnya

Tabel 1

Pelayanan kepada Pelanggan

\begin{tabular}{|c|c|c|}
\hline Unsur & YDSF & $\mathrm{BMH}$ \\
\hline \multirow[t]{2}{*}{ Pelanggan eksternal } & $\begin{array}{l}\text { fasilitas komunikasi: Majalah } \\
\text { al-Falah, SMS center, website, } \\
\text { facebook, dan telepon. }\end{array}$ & $\begin{array}{l}\text { Fasilitaskomunikasi:BMHNews, } \\
\text { media elektronik, dan telepon. }\end{array}$ \\
\hline & $\begin{array}{l}\text { Program: bidang keislaman, } \\
\text { masjid, dan santunan. }\end{array}$ & $\begin{array}{l}\text { Program: bidang pendidikan, } \\
\text { dakwah, dan bidang sosial dan } \\
\text { solidaritas kemanusiaan }\end{array}$ \\
\hline Pelanggan internal & Bagian amil: $12,5 \%$ & Bagian amil: $12,5 \%$ \\
\hline
\end{tabular}

beberapa kekurangan yang mereka miliki. Misalnya, perhatian pribadi kepada donatur secara khusus. Data yang terkumpul belum menunjukkan bahwa pihak muzakki terlibat dalam pembuatan program kerja. Nampaknya, seluruh aktifitas YDSF maupun $\mathrm{BMH}$ berawal dari inisiatif mereka sendiri. Padahal, bila saran atau usulan donatur ditampung dan diwujudkan dalam sebuah aktifitas, tentunya mereka akan lebih puas dengan pelayanan institusi pengelola zakat. kualitas lembaga.

\section{Penyelenggaraan Pelatihan}

Program pengadaan penyelenggaraan pelatihan dikhususkan untuk seluruh karyawan YDSF dengan tujuan up grading yang diadakan setiap tiga bulan sekali, atau juga keadaan yang kondisional sesuai dengan job description atau kebutuhan masing-masing

\footnotetext{
${ }^{30}$ Ririn, wawancara, 08 Juli 2011
} 
departemen. Termasuk juga program pengiriman karyawan untuk meningkatkan kualitas diri bagi karyawan yang dianggap membutuhkan. Pelatihan atau peningkatan kualitas diri yang diikuti oleh karyawan YDSF dapat diaplikasikan pada proses pemagangan untuk memantapkan ilmu yang diperoleh. Cara yang lain adalah YDSF bisa berperan sebagai salah satu tempat magang atau belajar oleh mahasiswa. Tujuan pembelajaran dan pelatihan managemen adalah mematangkan keahlian mereka tentang rencana strategis dan sistematis yang dimiliki YDSF. ${ }^{31}$

\section{Perbaikan Proses Secara Berkesinambungan}

Program kerja dan proses perbaikan yang berkesinambungan sangat mempengaruhi perkembangan YDSF jangka panjang. Visi dan misi yang telah ditetapkan merupakan sarana mewujudkan tujuan dari YDSF. Tujuan yang berdasarkan misi dan visi dari YDSF dirumuskan dalam bentuk rencana jangka pendek (kegiatan harian dan mingguan), rencana jangka menengah (kegiatan pada eventertentu, sepertimemperingatiharibesar Islam dan Ramadhan), dan tahunan (seperti pada tahun 2010 masa konsolidasi, 2011 masa ekspansi 1 dan 2012 masa ekspansi 2). Selain itu, ada beberapa kegiatan sebagai program kerja yang berkesinambungan dalam upaya meningkatkan mutu YDSF. Hal ini sebagai sasaran pembuktian program kerja yang sistematis dengan alur yang mengarah ke depan untuk kemajuan YDSF. ${ }^{32}$

Rencana-rencana yang tersusun secara sistematis untuk perbaikan secara berkala di YDSF tidak terlepas dari pengawasan proses yang dilakukan oleh tim pengawas. Pengawasan proses dilakukan oleh tim pengawas sebagai evaluasi berkala YDSF. Hal ini juga dilakukan untuk mengidentifitasi masalah yang dihadapiagar dapat ditemukan solusi terbaik.

Dalam proses pengawasan yang seimbang

\footnotetext{
${ }^{31}$ Ririn, wawancara, 8 Juli 2011

${ }^{32}$ Ririn, wawancara, 8 Juli 2011
}

dan sistematis, YDSF telah melakukan audit internal yang dilakukan oleh pengurus, pembina serta pengawas YDSF dan audit eksternal mandiri. Audit di YDSF merupakan sebuah kebutuhan. Hal ini dapat memotivasi seluruh karyawan agar tetap semangat untuk bekerja dan berkarya serta dapat lebih meningkatkan perbaikan yang berkesinambungan.

\section{Perbaikan Proses BMH yang Berkelanjutan}

\section{Peningkatan Kualitas}

Dalammeningkatkankualitas, dibutuhkan persiapan untuk upaya peningkatan yang matang. Artinya, dibutuhkan sarana dan prasarana untuk memfasilitasi program kerja atau rencana yang telah tersusun secara matang sebagai gerak langkah ke depan. Peningkatan kualitas tidak hanya berkonsentrasi pada kualitas lembaga namun jugakualitaskaryawan. Dalammeningkatkan kualitas lembaga, BMH memiliki program kerja yang sesuai dengan SOP BMH Pusat dan kemudian dikembangkan oleh setiap $\mathrm{BMH}$ Cabang. Untuk peningkatan kualitas $\mathrm{BMH}$, terlihat dari program kerja dan sarana yang digunakan cukup memenuhi demi kelancaran dan terwujudnya tujuan $\mathrm{BMH}$. Hal ini dapat dicontohkan secara konkrit, keterikatan antara sarana dan prasarana yang digunakan untuk meningkatkan kualitas BMH. Untuk hal ini, Bathy mengatakan,

\begin{abstract}
"Seperti diadakannya pengobatan masal di daerah tertentu dengan mengajak donatur ataupun mengundang dokter khusus sebagai sarana dalam melengkapi pengobatan tersebut, dengan tujuan agar pengobatan masal ini benar-benar bermutu dan bermanfaat. Selain itu BMH juga memiliki sarana prasarana seperti mobil kesehatan agar dapat menjangkau daerah-daerah terpencil". ${ }^{33}$
\end{abstract}

Sarana dan prasarana yang digunakan tersebut berkaitan dalam meningkatkan kualitas BMH, khususnya BMH Cabang Kota Malang.

\footnotetext{
${ }^{33}$ Bathy, wawancara, 06 Juli 2011
} 
Sedangkan untuk meningkatkan kualitas karyawan, tidak hanya pada jaminan kesehatan namun $\mathrm{BMH}$ juga memberikan sarana prasarana berupa laptop per-divisi dengan tujuan agar mempermudah proses manajeman dan kerja karyawan BMH serta pengembangan pribadi atau SDM karyawan $\mathrm{BMH}$ memberikan pelatihan ataupun training yang sesuai dengan job description atau kebutuhan per-divisi. Oleh sebab itu, beberapa karyawan sudah pernah mengikuti seminar atau pelatihan di beberapa tempat, seperti Surabaya tentang pengelolaan manajemen yang baik berdasarkan SOP BMH Pusat. ${ }^{34}$

\section{Penyelenggaraan Pelatihan}

Diadakannya pelatihan khusus untuk karyawan $\mathrm{BMH}$ yang diadakan sesuai kebutuhan (job description) pada waktu yang kondisional, bertujuan untuk meningkatkan SDM di BMH. Selain pelatihan, terdapat pula program khusus karyawan untuk peningkatan kualitas diri. Hal ini dapat dilakukan dengan pengiriman karyawan ke lembaga lain yang sejenis dan untuk selanjutnya diteruskan dengan pemagangan agar ilmu yang didapatkan dapat diaplikasikan setelah kembali ke BMH.

Pelatihan khusus atau pengiriman kar_ yawan ini bermanfaat untuk pengembangan diri karyawan dalam mengemban tugas yang dibebankan. Penyelenggaraan pelatihan dapat mendukung peningkatan kualitas diri karyawan dalam meningkatkan kualitas BMH secara keseluruhan.

\section{Perbaikan Proses Secara Berkesinambungan}

BMH mempunyai program kerja yang berkesinambungan untuk komitmen jangka panjang. Program tersebut berasal dari visi dan misi BMH. Komitmen jangka panjang melahirkan program atau rencana strategis jangka pendek dalam waktu mingguan, menengah untuk waktu bulanan, serta panjang yaitu satu tahun. Evaluasi dilakukan secara terus-menerus. Misalnya, evaluasi mingguan dilakukan setiap divisi, evaluasi

${ }^{34}$ Bathy, wawancara, 06 Juli 2011 bulanan diadakan antar divisi, dan evaluasi tahunan untuk seluruh karyawan BMH. Ketika terjadi kendala pada perbaikan proses komitmen jangka panjang, dapat dilakukan rapat secara kondisional untuk menemukan solusi dari permasalahan.

Perbaikan proses dengan komitmen jangka panjang yang dilakukan secara berkala tetap mendapatkan pengawasan khusus dari pihak Divisi SDM agar proses ini berjalan baik dan berhasil. Proses perbaikan komitmen jangka panjang yang saling berkesinambungan memberikan nilai plus terhadap BMH ketika dilakukan audit internal maupun eksternal. ${ }^{35}$

Dari uraian di atas, dapat diketahui bahwa YDSF dan BMH telah melakukan berbagai upaya untuk meningkatkan mutu program kerja yang berkesinambungan. YDSF dan BMH cukup paham bahwa kualitas adalah bagian yang tak dapat ditawar jika lembaga mereka ingin tetap hidup. Peningkatan pelayanan termasuk dengan mengirimkan karyawan ke berbagai pelatihan dapat dikatakan telah sesuai dengan semangat ini.

Halyang patut dicatat di sini adalah bahwa pelatihan yang diikuti disesuaikan dengan tugas pokok karyawan. Itu artinya pelatihan yang hanya sekedar menghabiskan anggaran atau hanya ikut-ikutan tidak terjadi di kedua lembaga ini. Orientasi profesionalisme sudah cukup mengakar dalam setiap keputusan yang diambil.

Perbaikan secara terus-menerus juga sudah dilakukan oleh kedua lembaga, YDSF dan BMH. Cara yang dilakukan adalah dengan mengevaluasi setiap program kerja yang telah didistribusikan sesuai dengan tugas masing-masing. Visi dan misi merupakan acuan dasar mereka. Ketika akan melakukan evaluasi, mereka bisa melakukan secara bertahap, mingguan, bulanan, hingga tahunan. Selain itu, pengauditan internal dan eksternal sudah mereka lakukan. Audit internal dilakukan oleh pengurus sedangkan audit eksternal dilakukan oleh auditor eks-

\footnotetext{
${ }^{35}$ Bathy, wawancara, 06 Juli 2011
} 
ternal independen.

Untuk mempermudah perbandingan kedua lembaga tersebut dalam hal perbaikan proses yang berkesinambungan, tabel 2 berikut ini mungkin bisa membantu.

Hal yang belum terungkap dalam perbaikan proses ini adalah tentang tahap-tahapan yang telah mereka lakukan selama beberapa tahun terakhir. Meskipun begitu, tekad YDSF dan BMH untuk menjadi lembaga pengelola zakat profesional tidak akan terwujud jika mereka tidak kreatif dalam melakukan kegiatan mereka. Hal ini setidaknya telah mereka buktikan dengan diraihnya predikat lembaga amil zakat tingkat nasional sejak tahun 2001 yang lalu.

Keikutsertaan Total Karyawan YDSF

Keterlibatan Karyawan dalam Kebebasan Berkarya
Posisi karyawan dengan pimpinan di YDSF sebagai mitra kerja salah satu penunjang keterlibatan karyawan untuk berkarya dalam mengembangkan YDSF. Meskipun tidak ada batasan hubungan status antara pimpinan dengan karyawan, YDSF tetap menganggap penting posisi pimpinan yang sifatnya mengarahkan dan sebagai penanggung jawab secara umum atas kualitas YDSF. Oleh sebab itu, keterlibatan antara pimpinan dengan seluruh karyawan beserta ketua per-departemen yang ditunjang dengan saling berhubungan baik dan lancar dalam mengembangkan manajemen YDSF dianggap penting. Salah satu buktinya adalah adanya koordinasi antara pimpinan dengan karyawan dalam beberapa kegiatan, misalnya, persiapan kegiatan di bulan Ramadhan. Jika terjadi ketidaksesuaian ide antara pimpinan dengan karyawan, maka pimpinan hanya mengarahkan jalan

Tabel 2

Perbaikan Proses

\begin{tabular}{|c|c|c|}
\hline Unsur & YDSF & $\mathrm{BMH}$ \\
\hline Peningkatan Kualitas & $\begin{array}{l}\text { Peningkatansarandanprasarana } \\
\text { kantor }\end{array}$ & $\begin{array}{l}\text { Peningkatansarandanprasarana } \\
\text { kantor }\end{array}$ \\
\hline Pelatihan & $\begin{array}{l}\text { up grading setiap tiga bulan } \\
\text { sekali sesuai dengan job } \\
\text { description Program pengiriman } \\
\text { karyawan untuk meningkatkan } \\
\text { kualitas diri. }\end{array}$ & $\begin{array}{l}\text { pelatihan khusus untuk } \\
\text { karyawan yang diadakan sesuai } \\
\text { kebutuhan }\end{array}$ \\
\hline Perbaikan berkesinambungan & $\begin{array}{l}\text { Visi dan misi jadi acuan } \\
\text { perumusan rencana jangka } \\
\text { pendek (kegiatan harian dan } \\
\text { mingguan), rencana jangka } \\
\text { menengah (kegiatan pada even } \\
\text { tertentu, seperti memperingati } \\
\text { hari besar Islam), dan tahunan. } \\
\text { Audit internal dilakukan oleh } \\
\text { pengurus sedangkan audit } \\
\text { eksternal dilakukan oleh auditor } \\
\text { independen yang dipilih. }\end{array}$ & $\begin{array}{l}\text { Program tersebut berasal dari } \\
\text { visidan misilembaga. Komitmen } \\
\text { jangka panjang melahirkan } \\
\text { program atau rencana strategis } \\
\text { jangka pendek dalam waktu } \\
\text { mingguan, menengah untuk } \\
\text { waktu bulanan, serta panjang } \\
\text { yaitu satu tahun. Evaluasi } \\
\text { dilakukansecaraterus-menerus, } \\
\text { baik mingguan, bulanan, atau } \\
\text { tahunan. } \\
\text { Audit internal dilakukan oleh } \\
\text { pengurus sedangkan audit } \\
\text { eksternal dilakukan oleh auditor } \\
\text { eksternal independen. }\end{array}$ \\
\hline
\end{tabular}


terbaik untuk masalah yang dihadapi di lapangan. Pimpinan menyadari bahwa yang mengetahui kondisi medan atau lapangan adalah karyawan yang bertugas. Rasa tidak nyaman yang dihadapi salah satu dari pimpinan atau karyawan dapat segera diatasi dengan melakukan rapat koordinasi antar tim ataupun seluruh karyawan yang terlibat dalam hal itu. Dengan demikian, karyawan dapat bekerja dengan baik tanpa merasa tertekan oleh pimpinan.

Seluruh karyawan YDSF saling bahumembahu untuk mengembangkan diri di segala bidang khususnya pengembangan YDSF. YDSF menganggap semua departemen sama pentingnya karena bila ada satu kegagalan yang ditimbulkan oleh seseorang merupakan kegagalan YDSF secara keseluruhan. Dengan demikian, seluruh karyawan dapat bekerja dengan proporsional sesuai dengan bidangnya dengan saling tukar pikiran atau membantu antar bidang. ${ }^{36}$

\section{Kerjasama Tim Untuk Kesatuan Tujuan}

Struktur organisasi yang lengkap mulai dari pimpinan sampai dengan karyawan dianggap dasar terpenting untuk operasional di YDSF. Selain menjadi dasar terpenting operasional, struktur organisasi merupakan sarana dalam mewujudkan komunikasi yang lancar antar anggota YDSF yang melahirkan budaya kerjasama tim yang sangat baik. YDSF selain mengadakan pendampingan tim sebagai koordinator yang bertanggung jawab, juga selalu menerapkan komunikasi atas segala sesuatu yang perlu untuk dikomunikasikan. Cara yang dilakukan adalah dengan diskusi pada waktu yang disepakati. Selain itu, YDSF menyediakan pembinaan antara karyawan dengan pengurus yang bertugas sebagai konsultan bimbingan untuk menghindari dan menyelesaikan konflik. ${ }^{37}$

Kerjasama tim yang baik dapat mewujudkan kesatuan tujuan dengan cara menyatukan visi dan misi seluruh komponen

\footnotetext{
${ }^{36}$ Ririn, wawancara, 08 Juli 2011

${ }^{37}$ Ririn, wawancara, 08 Juli 2011
}

YDSF. Caranya adalah menyatukan tujuan untuk meningkatkan kualitas dan menjalankan program kerja yang telah tersusun sistematis. Dari kerjasama tim yang baik, karyawan dapat memberikan saran konstruktif kepada pimpinan agar semangat kerja tetap terjaga baik untuk pimpinan dan karyawan lain.

\section{Pengambilan Keputusan}

Pada YDSF peran penting pada pimpinan salah satu tujuannya untuk pengambilan keputusan yang tepat berdasarkan ide karyawan yang dituangkan dalam rapat koordinasi dengan arahan yang telah diberikan oleh pimpinan lembaga. Prosedur pengambilan keputusan di YDSF dimulai dari koordinasi antar departemen atas ide yang akan disampaikan, kemudian pimpinan bisa memberikan saran atau arahan sebagai pandangan ide yang lebih baik. Atas pencampuran dua ide dari perwakilan tiap departemen dan pengarahan dari pimpinan maka anggota rapat dapat memilih hal yang dianggap paling manfaat terhadap kepentingan umat. Berdasarkan musyawarah mufakat dan kesepakatan dari anggota rapat dapat diputuskan solusi dari masalah yang dihadapi.

Dari prosedur pengambilan keputusan dengan cara seperti ini, pimpinan YDSF dianggap dapat berfikir jernih dan bijaksana dengan memberikan peluang terhadap karyawan untuk dapat mengembangkan idenya dalam berkarya di YDSF. Selain itu, pimpinan juga dapat menyeimbangkan antara rasio dengan perasaan untuk mengambil keputusan. Hal ini terlihat dari caranya yang dapat menerima gagasan karyawan yang berhubungan dengan kepentingan umat. Keputusan yang tegas dapat diambil dalam kondisi yang genting atas musyawarah mufakat dan selama tidak keluar dari batas visi dan misi serta tujuan dari YDSF. ${ }^{38}$

\footnotetext{
${ }^{38}$ Ririn, wawancara, 08 Juli 2011
} 


\section{Keterlibatan Karyawan BMH Dalam Kebebasan Berkarya}

Status antar karyawan bahkan dengan pemimpin dianggap sama atau disebut dengan mitra kerja. Alasan yang menjadikan seluruh karyawan sebagai mitra kerja yaitu agar hubungan antara pimpinan dan karyawan tidak terdapat sekat atau perbedaan. Dengan begitu, hubungan dan komunikasi dapat berlangsung lancar dan karyawan merasa nyaman tanpa adanya tekanan dan paksaan. Komunikasi atau koordinasi antar seluruh karyawan dengan pimpinan diadakan pada hari Sabtu. Dari hubungan yang baik dan elegan ini dapat memberikan peluang terhadap karyawan untuk mengembangkan ide fikirannya dan berkarya selama masih tetap sesuai dengan SOP BMH Pusat.

Seluruh posisi karyawan yang dianggap sebagai mitra kerja akan dapat saling bahumembahu untuk mencapai kualitas yang baik sesuai dengan tujuan BMH. Bathy mencontohkan kondisi karyawan sebagai mitra kerja terbukti dari tidak adanya divisidivisi yang dianggap lebih penting dari pada divisi yang lain, sebab semua divisi adalah teamwork. ${ }^{39}$ Seluruh karyawan dapat bekerja secara proporsional sesuai dengan tugas dan tanggung jawabnya serta dalam bidangnya masing-masing di BMH.

\section{Kerjasama Tim untuk Kesatuan Tujuan}

$\mathrm{BMH}$ memiliki struktur organisasi yang lengkap, mulai dari pimpinan lembaga, ketua divisi, hingga anggota divisi. Adanya komunikasi yang lancar dan baik melahirkan budaya kerjasama antara anggota atau karyawan di BMH. Hal ini memudahkan untukmenyatukanvisidanmisiantaraseluruh komponen $\mathrm{BMH}$ dengan menyatukan SOP dari lembaga tersebut. Meskipun BMH tidak melakukan pengadaan konsultan bimbingan dan konseling, namun jika terdapat konflik di antara para anggota karyawan, di setiap hari Rabu diadakan kajian rutin untuk seluruh

${ }^{39}$ Bathy, wawancara, 06 Juli 2011 karyawan yang bertujuan meminimalisasi terjadinya konflik.

Kemudahan yang diperoleh $\mathrm{BMH}$ dalam menyatukan visi dan misi seluruh komponen berawal dari saran konstruktif yang diberikan oleh karyawan terhadap pimpinan agar semangat tim tetap terjaga. Evaluasi berkala terhadap program kerja dijadikan sebagai jalan untuk menemukan solusi permasalahan yang dihadapi. Selain dari evaluasi berkala, BMH juga melakukan pengadaan pendampingan tim bagi tiaptiap divisi demi tercapainya tujuan yang diinginkan. ${ }^{40}$

\section{Pengambilan Keputusan}

Peran pimpinan di suatu lembaga dapat menjadi tolok ukur perkembangan sebuah lembaga. Mengambil keputusan untuk kepentingan bersama tidaklah mudah bagi pimpinan. Oleh sebab itu, pimpinan $\mathrm{BMH}$ dalam mengambil keputusan selalu berdasarkan musyawarah mufakat antara seluruh karyawan. Pengambilan keputusan yang berdasarkan mufakat ini adalah salah satu SOP dari BMH.

Namun untuk kondisi lain pimpinan $\mathrm{BMH}$ dapat menggunakan perasaan untuk mengambil keputusan, seperti ketika terjadi kecelakaan pada salah satu karyawan. Ketika karyawan tersebut memiliki dedikasi tinggi pada $\mathrm{BMH}$ maka bantuan tidak hanya dari ketentuan SOP tetapi juga dari anggaran dana kemanusiaan BMH Cabang Malang. Alasan $\mathrm{BMH}$ memberikan pemberian lebih saat kondisi seperti ini adalah karena sebagai balas budi terhadap karyawan yang memiliki dedikasi tinggi dan rasa saling tolong-menolong yang harus diterapkan oleh seluruh karyawan BMH.

Sedangkan untuk hal lain yang menyangkut kepentingan umat pimpinan $\mathrm{BMH}$ tidak berani mengambil keputusan dalam keadaan genting karena kesalahan dalam mengambil keputusan akan merugikan banyak orang. Di saat seperti ini,

${ }^{40}$ Bathy, wawancara, 06 Juli 2011 
jika tiap-tiap divisi setelah rapat koordinasi masalah belum terpecahkan maka seluruh karyawan akan dikumpulkan untuk rapat koordinasi. Jika kondisi masih panas dan belum menemukan titik temu, maka rapat koordinasi akan ditutup untuk sementara yang bertujuan agar dapat berfikir jernih untuk menemukan jalan keluar. Melihat cara pimpinan $\mathrm{BMH}$ dalam mengambil keputusan, pimpinan $\mathrm{BMH}$ sudah dapat dianggap sebagai pimpinan yang bijak dengan memberi kesempatan kepada seluruh karyawan untuk menemukan solusi. ${ }^{41}$

Dari uraian di atas dapat diketahui bahwa YDSF dan BMH telah berusaha melibatkan seluruh potensi untuk mencapai tujuan bersama. Untuk menggambarkan uraian di atas dalam bentuk sederhana dapat dilihat pada tabel 3.

Dari tabel tersebut dapat diketahui bahwa pimpinan dan karyawan dalam YDSF dan $\mathrm{BMH}$ bekerja saling bahu-membahu untuk menyelesaikan tugas-tugas lembaga. Pengambilan keputusan selalu melibatkan seluruh anggota lembaga sehingga tak ada kesalahpahaman di antara karyawan. Selain itu, Satu visi dan misi adalah perekat hubungan antara karyawan. Kerjasama satu tim telah mereka pancangkan dalam setiap kegiatan mereka.
Dari paparan dan analisis di atas, dapat diambil sebuah kesimpulan bahwa lembaga pengelola zakat semacam YDSF dan BMH telah menerapkan beberapa prinsip TQM sebagaimana yang disyaratkan oleh Tenner. Dua institusi ini telah melaksanakan tiga pilar TQM sesuai dengan konsisi masingmasing: pelayanan kepada pelanggan, perbaikan proses, dan pelibatan karyawan secara penuh untuk meraih tujuan lembaga. Dengan demikian, YDSF dan BMH telah mempunyai bekal untuk mencapai kesuksesan besar, sebagaimana harapan dari para pencetus TQM, di masa sekarang dan yang akan datang.

\section{Kesimpulan}

Beberapa kesimpulan yang dapat ditarik adalah sebagai berikut: pertama, Yayasan Dana Sosial al-Falah Malang dan Baitul Mal Hidayatullah Malang telah melakukan berbagai usaha untuk memberikan pelayanan terbaik untuk pelanggan, baik pelanggan eksternal maupun internal. Pelanggan eksternal mendapatkan perhatian dari kegiatan jemput donasi hingga layanan keluhan. Sarana yang digunakan juga beragam, dari media cetak hingga media elektronik. Meskipun demikian, ada sejumlah perbedaan yang dapat ditemukan,

Tabel 3

Keterlibatan Total

\begin{tabular}{|c|c|c|}
\hline Unsur & YDSF & BMH \\
\hline Kebebasan Berkarya & $\begin{array}{l}\text { Karyawan adalah motor } \\
\text { penggerak dan dapat berkarya } \\
\text { sesuai dengan tugasnya. } \\
\text { Atasan-bawahan tidak } \\
\text { dipertajamkarenahubungannya } \\
\text { adalah mitra. }\end{array}$ & $\begin{array}{l}\text { Status antar karyawan bahkan } \\
\text { dengan pemimpin dianggap } \\
\text { sama atau disebut dengan mitra } \\
\text { kerja }\end{array}$ \\
\hline Kerjasama Tim & $\begin{array}{l}\text { Strukturorganisasilengkap. Ada } \\
\text { konsultasi dan pendampingan } \\
\text { karyawanyangbermasalahdemi } \\
\text { tercapainya tim yang solid }\end{array}$ & $\begin{array}{l}\text { Struktur organisasi lengkap. } \\
\text { Tidak ada konsultan yang } \\
\text { mendampingi karyawan yang } \\
\text { bermasalah. Namun ada diskusi } \\
\text { terbuka bila ada karyawan yang } \\
\text { ingin mengungkap masalahnya. }\end{array}$ \\
\hline Pengambilan Keputusan & $\begin{array}{l}\text { Keputusan untuk kepentingan } \\
\text { orang banyak diambil secara } \\
\text { musyawarah mufakat. }\end{array}$ & $\begin{array}{l}\text { SOP Lembaga menyatakan } \\
\text { bahwa pengambilan keputusan } \\
\text { harus didasarkan pada } \\
\text { musyawarah. }\end{array}$ \\
\hline
\end{tabular}

${ }^{41}$ Bathy, wawancara, 06 Juli 2011 
antara lain inovasi pelayanan YDSF lebih terbuka dan bebas ketimbang BMH. Hal ini dapat dilihat dari upaya YDSF memanfaatkan kecanggihan teknologi untuk memudahkan pelanggan mendapatkan informasi dan layanan. Sementara itu, BMH Malang masih tergantung pada kebijakan pelayanan pelanggan yang ditentukan oleh BMH Pusat. Kedua, Yayasan Dana Sosial alFalah Malang dan Baitul Mal Hidayatullah Malang telah melakukan berbagai usaha untuk melakukan perbaikan terus-menerus untuk mencapai visi dan misi mereka. Sejumlah program seperti pengiriman karyawan ke beberapa jenis pelatihan seringkali dilakukan untuk meningkatkan kemampuan personel karyawan. Kegiatan semacam pembuatan rencana kerja hingga evaluasi program kerja mereka lakukan secara konsisten dan berkesinambungan. Visi dan mi-

\section{DAFTAR PUSTAKA}

Deming, W. Edwards. 2002. Out of the Crisis. Cambridge: MIT Press.

Gaspersz, Vincent. 2001. Total Quality Management, Jakarta: Gramedia Pustaka Utama.

George, Stephen, and Arnorld Weimerskirch. 1994. Total Quality Management, Strategies and techniques Proven at Today's Most Successful Companies, New York: John Wiley and Sons, Inc.

Idris, Safwan. 1997. Gerakan Zakat dalam Pemberdayaan Ekonomi Umat. Pendekatan Transformatif. Jakarta: Citra Putra Bangsa.

Nasution, M.N. 2001. Manajemen Mutu Terpadu.Jakarta: Ghalia Indonesia.

Qardhawi, Yusuf. 1997. Fiqh al-Zakat. Jilid I. Beirut: Muassasah al-Risalah.

Shihab, M. Quraish. 2000. Tafsir Al-Mishbah. Tangerang: Lentera Hati.

Sudewo, Eri. 2004. Manajemen Zakat. Jakarta: Institut Manajemen Zakat.

Sudirman. 2007. Zakat dalam Pusaran Arus Modernitas, Malang: UIN Malang Press. si lembaga menjadi acuan utama dalam membuat program kerja. Audit internal dan eksternal juga telah mereka lakukan meskipun dengan motode yang berbeda. Ketiga, Yayasan Dana Sosial al-Falah Malang dan Baitul Mal Hidayatullah Malang telah melakukan berbagai usaha untuk melibatkan seluruh potensi yang dimiliki lembaga guna mencapai pelayanan yang berkualitas. Struktur organisasi telah lengkap untuk mencapai tim yang solid. Semangat kerja satu tim mewarnai aktifitas mereka sehingga atasan dan bawahan tidak lagi menunjukkan hirarkhi tugas dan jabatan melainkan sebagai mitra kerja yang saling melengkapi. Hanya saja, untuk pendampingan karyawan yang bermasalah, YDSF mempunyai tim konsultan yang setiap saat dapat membantu meringankan atau memecahkan masalah yang dihadapi.

Sudirman, dan Risma Nur Arifah. 2007. "Manajemen Zakat di Yayasan Dana Sosial Al-Falaf, Lazis Sabilillah, dan Lagzis Raden Fatah," Laporan Penelitian, Malang: Pusat Kajian Zakat dan Wakaf.

Tenner, Arthur R., Irving J. DeToro. 1992. Total Quality Management, Three Steps to ContinuousImprovement, Massachusetts: Addison-Wesley Publishing Company, Inc.

Tjiptono, Fandi, dan Gregorius Chandra. 2007. Service, Quality \& Satisfaction, Yogyakarta: Andi.

Yafie, Ali. 1995. Menggagas Fikih Sosial: Dari Soal Lingkungan Hidup, Asuransi Hingga Ukhuwah, Bandung: Mizan.

\section{Peraturan Perundang-Undangan}

Undang-Undang Nomor 38 Tahun 1999 tentang Pengelolaan Zakat.

\section{Majalah}

Majalah Zakat, Edisi II, bulan Agustus 2003

Republika, 5 November 2008 
Website

www.bmh.or.id. diakses tanggal 5 Juli 2011

www.dompetdhuafa.org diakses tanggal 10 April 2011 www.islamicrelief.com diakses tanggal 2 Mei 2011

www.ydfs.or.id diakses tanggal 5 Juli 2011 